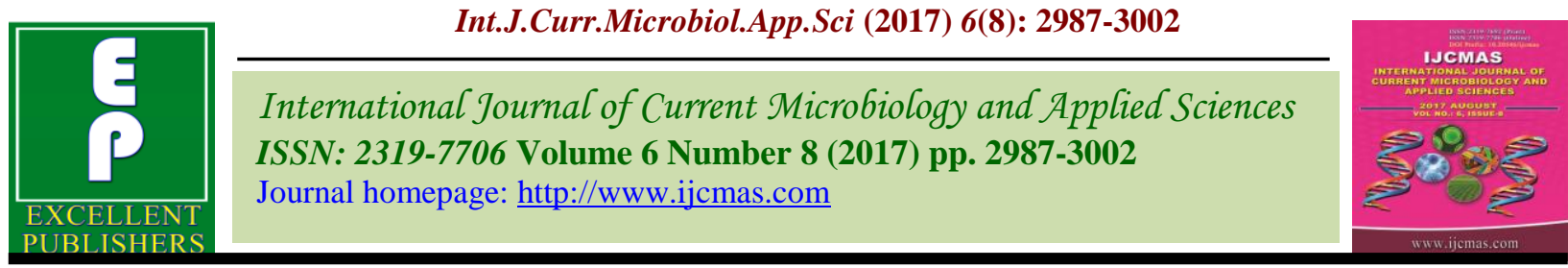

Original Research Article https://doi.org/10.20546/ijcmas.2017.608.358

\title{
Studies on Variability, Identification of Xanthomonas axonopodis pv. punicae Isolates and Screening of Gamma $(\gamma)$ Irradiated Seed Derived Progenies and Germplasms of Pomegranate
}

\author{
Dadepeer A. Peerajade ${ }^{1 *}$, Narayan Moger ${ }^{1}$ and H.B. Patil ${ }^{2}$ \\ ${ }^{1}$ Department of Biotechnology, Institute of Agribiotechnology (IABT), University of \\ Agricultural Sciences, Dharwad, Karnataka, India \\ ${ }^{2}$ Department of Horticulture, University of Horticultural Sciences, Bagalkot, Karnataka, India \\ *Corresponding author
}

A B S T R A C T

Keywords

Bacterial blight,

Pomegranate, polymorphism,

Xanthomonas axonopodis $p v$.

Punicae, in vivo and in vitro.

Article Info

Accepted:

23 June 2017

Available Online:

10 August 2017
Bacterial blight is one of the most important disease of Pomegranate caused by bacterium Xanthomonas axonopodis pv. punicae (Xap). The disease is characterized by small, irregular, translucent, water soaked spots with light to dark necrotic centre surrounded by prominent yellow margin on leaves. The isolates were made from the symptomatic samples collected from four districts of Karnataka viz., Vijayapur, Bagalkot, Koppal, and Chitradurg. The variability was studied among the four isolates of Xanthomonas axonopodis pv. punicae by using morphological, cultural and molecular characteristics. Xanthomonas axonopodis pv. punicae pure culture was isolated and confirmed its pathogenicity on susceptible variety Bhagawa and molecular identification was carried out using specific marker genes viz., 16S rRNA and gyrB. All four isolates were screened with three different markers viz., REP, ERIC and BOX to distinguish among them at genetic level. Amplification of ERIC, BOX and Rep region DNA from four isolates of pomegranate bacterial blight from four locations with three different primers yielded a total 28, 20 and 24 bands respectively with monomorphic banding pattern in all four isolates and amplicon size ranging from 300 to $2000 \mathrm{bp}$ with BOX and ERIC primers, whereas in case of Rep primers the range is 200 to $1000 \mathrm{bp}$ only. From this, it is confirmed that not much variation is existing in the collected isolates. Hence, isolate from Vijayapur (XapI) was used for further screening of the genotypes against bacterial blight both in vivo and in vitro.

\section{Introduction}

Pomegranate (Punica granatum L.), a favorite table fruit in tropical and sub-tropical regions of the world belongs to family Punicaceae, having chromosome number $(2 \mathrm{n}=16)$ and is an ancient fruit with rich history and believed to have originated from Iran but extensively cultivated in Mediterranean region especially in Spain, Morocco, Egypt and Afghanistan. It is also grown in drier parts of Southeast Asia, Burma, China, Japan, USA, West Indies,
Russia, Bulgaria, Tropical America, Southern Italy and India (Priya et al., 2016). In India it is cultivated over an area of 131.00 thousand hectare with a production of 1346.00 thousand MT (Anonymous 2015). Amongst different states growing pomegranate, Maharashtra is the largest producer with a total area of 90 thousand hectare and production of 945.00 thousand MT followed by Karnataka, Andhra Pradesh, Gujarat and 
Rajasthan. In Karnataka the area and production of pomegranate is 16.6 thousand hectare and 134.20 thousand MT, respectively (Anonymous, 2015). Area under pomegranate is increasing worldwide because of its hardy nature, wider adaptability, drought tolerance, higher yields, excellent keeping quality and remunerative prices in domestic as well as export markets.

India is the leading pomegranate producer which contributes nearly $50 \%$ of the world's production (Wayde et al., 2015). It thrives well in dry tropics and sub-tropics and performs very well in soils of low fertility status, adding to that it is salt tolerant too. The fruit has a wide consumer preference for its attractive, juicy, sweet, acidic and refreshing arils. Pomegranate fruits are good source of carbohydrates and minerals such as calcium, iron and sulphur that possess pharmaceutical and therapeutic properties. It is rich in vitamin $\mathrm{C}$ and citric acid is the predominant organic acid in pomegranate (Malhotra et al., 1983).

Pomegranate production is confronted with many problems like other crops. Inherent constraints are non-availability of suitable varieties, prone to environmental vagaries, nutritional deficiencies, physiological disorders, post-harvest glut, post-harvest losses, improper storage, lack of marketing facilities and price fluctuations. Biotic constraints are pest and disease problems. Although, 25 to 30 per cent of total cost of production is spent on plant protection, yet the biotic constraints could not be managed effectively. Among the diseases infecting pomegranate, a bacterial disease popularly known as 'bacterial blight' caused by Xanthomonas axonopodis pv. punicae, which was once a minor disease has emerged as a major production constraint resulting in sever yield loss both in terms of quality and quantity in the recent years in India (Hingorani and Mehta 1952; Chand and
Kishun 1993; Vauterin et al., 1995; Benagi and Kumar 2009; Sharma et al., 2010). Chand and Kishun (1991) reported the epidemics of bacterial blight of pomegranate causing 60 to 80 per cent losses at Indian Institute of Horticultural Research (IIHR) experimental plots. The species designation of pomegranate blight bacterium has recently been changed from $X$. campestris pv. punicae to $X$. axonopodis based on gyrB sequence (Parkinson et al., 2009). The bacterial blight disease caused by $X$. axonopodis is a major threat for pomegranate cultivation (Mondal and Sharma, 2009; Mondal and Singh, 2009; Petersen et al., 2010; Mondal et al., 2012). It is a serious disease in the states of Karnataka, Maharashtra and Andhra Pradesh and causes losses to the extent of 60 to $80 \%$ in India (Mondal and Mani, 2009).The disease symptoms appearing on all plant parts, initially small, irregular, grayish black, water soaked lesions were observed on leaves which enlarged with the progression of the disease. Similarly blackish lesions were observed, on nodes of this stem later on resulting in canker formation with depressed growth. Disease symptoms were also reported prominent on developed fruit where the lesion enlarged coalesced and covered the entire fruit surface (Sharma, 2006; Sharma et al., 2008).

The disease spreads from infected orchard to healthy one, through pomegranate cuttings. The disease become predominant and appearing in epiphytotic form during last five years in pomegranate growing states of South-West India, including Maharashtra and Karnataka. Nevertheless, the disease also spread rapidly to the states of Rajasthan, Gujarat, parts of Haryana and Uttar Pradesh due to the bulk movement of planting materials (cuttings) of most popular and bacterial blight susceptible cultivar, Bhagwa from Maharashtra (Kumar et al., 2009; Mondal and Sharma, 2009; Mondal et al., 2012). The disease continued to damage the 
crop for subsequent years and farmers have adopted all possible and available protection measures, the disease could not be managed effectively due to rapid buildup of inoculum and the boon of this commercial fruit crop turned as a big bane to the farmers. The disease accounted up to $70-100$ per cent loss during 2006 in Karnataka and Maharashtra resulting in wipe out of pomegranate. During the year 2007, the total production of pomegranate in India was down by 60 per cent (Raghavan, 2007). Many growers finding no options to mitigate the disease effectively uprooted their crop due to unbearable losses. The disease has been observed as serious threat to the cultivation of recommended varieties of pomegranate. The control of plant pathogens relies on the ability to identify infecting species. Of the several disease management strategies, varietal resistance is considered as the best alternative.

Genetic improvement of fruits is essential for increasing the productivity. The major problems with fruit breeding work are long life cycle and the large juvenile period has hampered fruit breeding work. Preliminary screening of available pomegranate germplasm revealed that all the accessions are susceptible to bacterial blight (Jyoti, 2017) and not much variability is existing. Exploiting natural or induced genetic diversity is a substantiated strategy in the improvement of all major food crops and the use of mutagenesis to create novel variation is particularly valuable in those crops with restricted genetic variability (Parry et al., 2009). Breeding strategies in pomegranate include seedling selection, hybridization and mutation breeding. In pomegranate, seed propagation is relatively straightforward, but seed-derived progenies represent a heterogeneous population (Jalikop and Kumar, 1990). It is known that irradiation of seeds increases mutation frequency and in turn promote gene recombination and widen the mutation spectrum (Larik et al., 2009) and introduce considerable variability among many useful traits including plant size, blooming time and fruit ripening, fruit color, self-thinning resistance to pathogens (Jain 2010). By considering the severity of this pathogen and susceptibility of the cultivar, it is essential to develop diagnostic primer in order to restrict the spread of the $X$. axonopodis pv. punicae. It would be useful to generate disease free planting material and also exploited to ensure the presence of this pathogen in to suspected planting materials. Therefore, keeping in view these facts, the present study was proposed on variability, identification and development of DNA based molecular markers for detection of oily spot pathogen of pomegranate.

\section{Materials and Methods}

Collection, isolation, pathogenicity and identification of Xanthomonas strains from infected sample

The investigation was undertaken to assess variability and development of DNA based marker for identification $X$. axonopodis $p v$.punicae causing oily spot disease of pomegranate. This study was conducted at Department of Biotechnology \& Crop improvement, Horticulture Research and Extension Station, Vijayapur (Tidagundi), affiliated to University of Horticultural Sciences, Bagalkot (Karnataka). The oily spot infected samples of pomegranate were collected from Vijayapur, Bagalkot, Koppal, and Chitradurga districts of Karnataka state as the list given in table 1. The pathogen $X$. axonopodis was isolated from leaves, fruits samples. Infected lesions was cut by using sterilized scalpel blade followed by sterilization with $0.1 \% \mathrm{HgCl}_{2}$ and $70 \%$ ethanol for 15 second, then thoroughly rinsed with sterile distilled water. The resulting suspension was streaked on Nutrient agar 
(NA) plates and incubated at $28^{\circ} \mathrm{C}$ in an incubator for 48-72 hr. Single colonies having circular, convex, mucoid, shiny and yellow morphological characteristics of $X$. axonopodis $p v$. punicae were picked by sterilized loop and purified cultures were obtained by streaking on fresh NA medium. Then cultures were stored in the refrigerator at $4^{\circ} \mathrm{C}$, which served as a stock culture for further studies. The bacterial isolates were subjected to conventional diagnostic tests using standard protocols for Morphological, cultural, and pathogenic characterization as shown in table 2 . The four pure cultures obtained after isolation from the diseased samples of all the regions were designated as different isolates from Xap1 to Xap4 and maintained further use(Plate 3)

The susceptible variety Bhagawa was selected for proving pathogenicity on pomegranate plants, which were grown in earthen pots of $30 \mathrm{~cm}$ size filled with clay loam soil and FYM in 1:1 ratio in the polyhouse. The temperature and relative humidity in the polyhouse was maintained to $25 \pm 5{ }^{\circ} \mathrm{C}$ and 70 80 per cent, respectively. The pathogen cell suspension of all four cultures was independently $\left(2.5 \times 10^{8} \mathrm{cfu} / \mathrm{ml}\right)$ sprayed on five weeks old plant that attained $15-20 \mathrm{~cm}$ height with 5-10 leaves per shoot. The characteristic symptoms observed on pomegranate leaves after 15 to 18 days of inoculation as small, water-soaked, brown to black colored circular to irregular lesions, surrounded by yellow halo. Re-isolations were carried out from these lesions with the original culture to confirm the identity of the pathogen (Plate 1).

One month old susceptible and resistance varieties of 14 pomegranate genotypes were transplanted into the pots containing sterilized soil amended with necessary nutrients. The seedlings were regularly watered and exposed to sufficient sunlight. To prove the pathogenicity of $X$. axonopodis $p v$. punicae, it was mass multiplied in NA broth. Two months old pomegranate plants were sprayed with prepared bacterial suspension ( 0.4 to 0.6 OD). The inoculated plants were kept in polyhouse for further observations and data recorded using disease severity scale (Table 4) given by Singh et al., (2015).

The disease on leaves was scored for 475 genotypes ( $\gamma$-rays irradiated seed derived progenies and 23 popular germplasms) under polyhouse (in vitro) as well in field level (in vivo) during Mrigbahar 2014-15 and 201516. For in vitro study One month old saplings of 475 pomegranate lines were planted in the pots containing sterilized soil amended with necessary nutrients. The seedlings were regularly watered and kept in polyhouse for further establishment. $X$. axonopodis $p v$. punicae, was separately multiplied in NA broth as well as in petriplates using NGA medium, later inoculated with a loop full of active stage bacterial culture. The inoculated flasks and plates were incubated for 72 hour at $28{ }^{\circ} \mathrm{C}$. The inoculum solution was set to OD between $0.4-0.6$ at $600 \mathrm{~nm}$ using biospectrophotometer (Eppendorf). Two months old pomegranate plants were sprayed with water and kept in polyhouse. The leaves of the pre-incubated pomegranate plants were inoculated by spraying with prepared colony suspension of the bacteria with an automizer. The inoculated plants were kept in polyhouse for further observations. Similarly for in vivo screening, plants were inoculated by spraying with prepared colony suspension of the bacteria with an sprayer and and observations recorded subsequently using the disease scale (Singh et al., 2015).

\section{Genomic DNA extraction}

Single colony of $X$. axonopodis pv. punicae, bacteria was inoculated in NA broth and incubated at $28{ }^{0} \mathrm{C}$ for 72 hours. Cells were 
harvested by centrifuging at 12,000 rpm for 5 min. Cells were lysed by treating with $550 \mu \mathrm{L}$ buffer (10 mM EDTA + $10 \mathrm{mM}$ Tris base, $\mathrm{pH}$ 8) and $20 \mu \mathrm{L}$ of freshly prepared lysozyme $(0.01 \mathrm{mg} / \mathrm{mL}$ of buffer) and incubated in a micro centrifuge tube for $30 \mathrm{~min}$ at $35{ }^{0} \mathrm{C}$. Cell suspension was treated with $100 \mu \mathrm{l} 5 \mathrm{M}$ $\mathrm{Nacl}+76 \mu \mathrm{l}$ of $10 \%$ SDS and $80 \mu \mathrm{l}$ of $\mathrm{CTAB} / \mathrm{Nacl}$ and tubes were incubated at 65 ${ }^{0} \mathrm{C}$ for $20 \mathrm{~min}$. Tubes were cooled down to room temperature and to remove protein contaminants equal volume of chloroform: isoamyl alcohol (24:1) was added, mixed thoroughly and centrifuged at $12,000 \mathrm{rpm}$ for $10 \mathrm{~min}$ at room temperature. Supernatant was carefully transferred to fresh sterile $1.5 \mathrm{~mL}$ centrifuge tubes and 1.5 volume of ice-cold isopropanol was added to precipitate DNA and incubated at $-20{ }^{0} \mathrm{C}$ overnight. Tubes were then centrifuged at $12,000 \mathrm{rpm}$ for 10 min at $4{ }^{0} \mathrm{C}$ and the pellet was washed twice with $70 \%$ ethanol. Tubes were air dried completely at room temperature and the DNA was dissolved in sterile nuclease free water and stored at $4{ }^{0} \mathrm{C}$. Quantification of DNA was performed by measuring the absorbance at $260 \mathrm{~nm}$ in Nanodrop (Eppendorf), quality of the DNA was analysed in $0.8 \%(\mathrm{w} / \mathrm{v})$ agarose gel and DNA was diluted to uniform concentration of $100 \mathrm{ng} / \mu \mathrm{L}$ for further use (Plate 4).

\section{Polymerase chain reaction}

The four strains of $X$. axonopodis pv. Punicae were confirmed with species specific marker genes viz., 16S rRNA and gyrB (Table 2). Hence, the PCR was performed with the standard protocol. The PCR amplification of $16 \mathrm{~S}$ rRNA and gyrB primers were performed using 100 ng DNA template, 1X PCR Buffer, $200 \mu \mathrm{M}$ dNTPs mix, $0.4 \mu \mathrm{M}$ primer and $1 \mathrm{U}$ Taq DNA polymerase (Merck, Bangalore, India) and sterile distilled water to make final volume of $20 \mu \mathrm{L}$. PCR amplification was conducted with a thermo cycler (Eppendorf Vapo Protect, Germany). The amplification were carried out with an initial denaturation $94{ }^{0} \mathrm{C}$ for $4 \mathrm{~min}$, followed by 30 cycles of 30 sec denaturation at $94{ }^{0} \mathrm{C}, 45 \mathrm{sec}$ of primer annealing at $55{ }^{0} \mathrm{C}, 1 \mathrm{~min}$ extension at $72{ }^{\circ} \mathrm{C}$. The final extension step was for $10 \mathrm{~min}$ at $72^{0} \mathrm{C}$.

All four isolates were screened with three different markers viz., REP, ERIC and BOX (Table 3) to distinguish among them at genetic level. The PCR amplification of all three primers were performed independently using 100 ng DNA template, 1X PCR Buffer, $200 \mu \mathrm{M}$ dNTPs mix, $0.4 \mu \mathrm{M}$ primer and $1 \mathrm{U}$ Taq DNA polymerase (Merck, Bangalore, India) and sterile distilled water to make final volume of $20 \mu \mathrm{L}$. PCR amplification was conducted with a thermo cycler (Eppendorf Vapo Protect, Germany). The amplification were carried out with an initial denaturation $94{ }^{0} \mathrm{C}$ for $4 \mathrm{~min}$, followed by 30 cycles of 30 sec denaturation at $94{ }^{0} \mathrm{C}, 45$ seconds of primer annealing at $55^{\circ} \mathrm{C}, 1 \mathrm{~min}$ extension at $72{ }^{0} \mathrm{C}$. The final extension step was for 10 min at $72{ }^{\circ} \mathrm{C}$.

\section{Results and Discussion}

A survey was conducted in year 2013-14 at pomegranate growing region of Karnataka. A pathogen $X$. axonopodis pv. punicae was purified from infected fruits and leaf sample and confirmed by proving their pathogenicity and PCR based by $16 \mathrm{~S}$ rRNA and gyrB specific primer(Plate 5). The molecular variability was assessed by REP, ERIC and BOX analysis and the data have been utilized for the development of DNA based marker for identification of $X$. axonopodis pv.punicae (Plate 6).

\section{Pathogenicity test}

The four putative isolates of $X$. axonopodis pv.punicae were collected from different pomegranate growing regions of Karnataka, isolated and purified by single spore method. 
The pathogenic potential of all four isolates was proved on the pomegranate cv. Bhagwa. Pure cultures of $X$. axonopodis pv. punicae were inoculated on pomegranate cv. Bhagwa, by spraying method. A known concentration of aqueous cell suspension of bacterial inoculums was sprayed to the pomegranate leaves in healthy tree pot. Control plant was inoculated by same way with sterile distilled water and maintained under humidity of 70 $80 \%$. The observations were recorded since 6 to 9 days after inoculation. Primarily, the symptoms appeared on leaves as irregular water soaked spots. Later on these spots appeared on the leaves with yellow 'halos' on axial side through rough texture. Further reisolation of pathogen form infected leaves through single colony method was accomplished and compared with original culture. The results obtained in the present study on morphological characters were in agreement with the reports of Hingorani and Singh (1959); Kanwar, 1976; Manjula and Khan, 2002; Kirankumar, 2007; Yenjerappa, 2009; Wyder et al., 2015).The isolation, purification and pathogenicity test of $X$. axonopodis pv. punicae was done by several researchers. However, the isolation of such slow growing $X$. axonopodis pathogen is usually difficult due to the masking effect of fast growing, yellow pigmenting bacteria. Various types of media have been used for isolation. Among which nutrient agar medium was best for isolating bacterium (Manjula and Khan, 2003).

The isolates of Xanthomonas axonopodis $p v$. punicae differed in respect of size of colony as they developed medium to large, small to medium and small colonies. The isolates of Xanthomonas axonopodis pv. punicae also differed greatly in shape of colony as some of bacterial isolates produced circular, while others are circular to irregular in shape (Table 5). The colour of the colony also differed greatly as the isolates were creamish yellow, light brown, light yellow in color. Only two isolates produce fuscan (brown pigment) in the medium while remaining isolates couldn't produce any brown pigmentation. The number of days taken for the appearance of bacterial colonies has also differed to some extent that the isolates were appeared 4 to 5 days after streaking on Nutrient Agar (NA) at $28 \pm 1^{\circ} \mathrm{C}$. These results indicated the presence of variability with respect to colony morphology of different isolates of $X$. axonopodis pv. punicae. Similar observations were recorded by Manjula and Khan (2002).

The isolates showed variability with respect to colony diameter and growth rate (Table 6). Among four isolates screened on solid media, Xap3 isolate (Koppal) showed maximum growth (with $0.33 \mu \mathrm{m}$ diameter) compared to all other isolates and least growth was recorded in Xap2 (Bagalkot) isolate $(0.24 \mu \mathrm{m}$ diameter).

This implies to the variation among the isolates of $X$. axonopodis $p v$. punicae. Present findings are comparable with the report by Hingorani and Singh (1959). They opined that, nutrient agar (NA) was the best media for the cultivation of pomegranate bacterium.

The data in table 7 revealed that all four isolates of Xanthomonas axonopodis $p v$. punicae symptoms after 15 days of inoculation. All the isolates exhibits water soaked, circular to irregular, dark brown symptoms on leaves (Plate 1) of Bhagawa variety.

The data in table 8 reveal that, there was significant difference within Xanthomonas axonopodis pv. punicae isolates with respect to their virulence and reaction with different varieties. Among the test isolates, Xap 1 was found to be virulent (PDI 42.38) across the varieties and was superior over other isolates viz., Xap2, Xap3 and Xap4 which were 
statistically on par and were rated as moderately virulent (Fig. 1).

Pomegranate varieties expressed variation (Fig. 2) in their susceptibility to Xanthomonas axonopodis pv. punicae. The variety Bhagawa recorded highest mean PDI (53.16) followed by P-16 (PDI 52.49), P-13 (51.83) and Ganesh (PDI 49.49) and rated as highly susceptible. Variety 'Patna 5' shown moderately susceptible with mean PDI of 11.00 whereas, Nana as tolerant (PDI 7.00). This study indicates that all leading varieties are susceptible to bacterial blight.

Table.1 Collection of bacterial isolates from different locations of Karnataka

\begin{tabular}{|c|l|l|l|l|}
\hline Isolate & Place of collection & District & Plant part & Variety \\
\hline Xap 1 & Tidagundi & Vijayapur & Leaf & Bhagawa \\
\hline Xap 2 & Kaladagi & Bagalkot & Leaf & Bhagawa \\
\hline Xap 3 & Munirabad & Koppal & Leaf & Bhagawa \\
\hline Xap 4 & Hiriyur & Chitradurg & Leaf & Bhagawa \\
\hline
\end{tabular}

Table.2 Characterization of $X$. axonopodis pv. Punicae with specific marker genes 16 sRNA and $g y r$ B

\begin{tabular}{|c|c|c|c|c|}
\hline $\begin{array}{c}\text { Sl. } \\
\text { No. }\end{array}$ & Primers & Sequence (5'-3') & $\begin{array}{c}\text { Annealing } \\
\text { temperature } \\
\left({ }^{0} \mathrm{C}\right)\end{array}$ & $\begin{array}{l}\text { Size } \\
\text { (bp) }\end{array}$ \\
\hline 1 & 16S rRNA & $\begin{array}{l}\text { Xsp16SRFWD2- } \\
\text { CTTACGCTAATACCGCATATACG } \\
\text { Xsp16SREV1- } \\
\text { CTGATCTGCGATTACTAGCGA }\end{array}$ & 55 & 761 \\
\hline 2 & gyrB & $\begin{array}{lr}\text { Forward } & 5 \text { 'GTTGATGCTGTT } \\
\text { CACCAGCG3' } & \\
\text { Reverse } & \text { 5'CATTCATTT } \\
\text { CGCCCAAGCCC3, } & \end{array}$ & 55 & 491 \\
\hline
\end{tabular}

Table.3 Primer sequence for molecular variability studies of X. axonopodis pv. Punicae

\begin{tabular}{|c|l|l|c|}
\hline $\begin{array}{c}\text { Sl. } \\
\text { No. }\end{array}$ & \multicolumn{1}{|c|}{ Primer } & \multicolumn{1}{|c|}{ Nucleotide sequence } & $\begin{array}{c}\text { Annealing } \\
\text { temperature }\end{array}$ \\
\hline \multirow{2}{*}{1} & REP1R-I & 5' IIICGICGICATCIGGC 3' & $44^{\circ} \mathrm{C}$. \\
\cline { 2 - 4 } & REP2-I & 5' ICGITTATCIGGCCTAC 3' & \\
\hline \multirow{2}{*}{2} & ERIC1R & $5^{\prime}$ 'ATGTAAGCTCCTGGGGATTCA3' & $52^{\circ} \mathrm{C}$. \\
\cline { 2 - 4 } & ERIC2 & $5^{\prime}$ AAGTAAGTGACTGGGGTGAGCG 3' & \\
\hline 3 & BOXA1R & $5^{\prime}$ 'CTCCGGCAAGGCGACGCTGAC3' & $53^{\circ} \mathrm{C}$. \\
\hline
\end{tabular}


Table.4 Disease reaction scale for bacterial blight of pomegranate on leaves

\begin{tabular}{|c|c|l|l|}
\hline $\begin{array}{c}\text { Numerical } \\
\text { rating }\end{array}$ & $\begin{array}{c}\text { Percentage } \\
\text { blighted area } \\
\text { on leaves }\end{array}$ & \multicolumn{1}{|c|}{ Description } & \multicolumn{1}{|c|}{ Reaction } \\
\hline 0 & Disease free & Disease not seen & Resistant \\
\hline 1 & $1-10$ & $\begin{array}{l}\text { Disease not easily visible, very few units/plant } \\
\text { found diseased after careful search }\end{array}$ & Tolerant \\
\hline 2 & $11-25$ & $\begin{array}{l}\text { Disease visible easily in each direction but } \\
\text { most (75\%) of the units look healthy }\end{array}$ & $\begin{array}{l}\text { Moderately } \\
\text { susceptible }\end{array}$ \\
\hline 3 & $26-50$ & $\begin{array}{l}\text { Both disease and healthy units are equally } \\
\text { observed }\end{array}$ & $\begin{array}{l}\text { Highly } \\
\text { susceptible }\end{array}$ \\
\hline 4 & $51-75$ & $\begin{array}{l}\text { Disease seen easily with only some healthy } \\
\text { units }\end{array}$ & $\begin{array}{l}\text { Highly } \\
\text { susceptible }\end{array}$ \\
\hline 5 & $76-100$ & $\begin{array}{l}\text { Almost all units are diseased, with few } \\
\text { healthy units seen on careful search }\end{array}$ & $\begin{array}{l}\text { Highly } \\
\text { susceptible }\end{array}$ \\
\hline
\end{tabular}

Table.5 Cultural variability among isolates of Xanthomonas axonopodis pv. Punicae

\begin{tabular}{|l|l|l|l|c|c|}
\hline Isolate & Size of colony & Shape of colony & \multicolumn{1}{|c|}{$\begin{array}{c}\text { Colour of } \\
\text { colony }\end{array}$} & $\begin{array}{c}\text { Fuscan } \\
\text { production }\end{array}$ & $\begin{array}{c}\text { Appearance } \\
\text { of colony } \\
\text { (No. of days) }\end{array}$ \\
\hline Xap1 & Medium to large & Circular & Creamish yellow & - & 5 \\
\hline Xap2 & Medium to large & Circular to irregular & Light brown & + & 4 \\
\hline Xap3 & Small to medium & Circular & Light brown & + & 5 \\
\hline Xap4 & Medium to large & Circular to irregular & Light yellow & - & 4 \\
\hline
\end{tabular}

Table.6 Morphological variability among isolates of Xanthomonas axonopodis pv. Punicae

\begin{tabular}{|c|c|c|c|c|c|c|}
\hline \multirow[b]{2}{*}{ Isolate } & \multicolumn{2}{|c|}{ Length $(\mu \mathrm{m})$} & \multicolumn{2}{|c|}{ Breadth $(\mu \mathrm{m})$} & \multirow[b]{2}{*}{$\begin{array}{c}\text { Flagellar } \\
\text { movement }\end{array}$} & \multirow[b]{2}{*}{$\begin{array}{c}\text { Endospore } \\
\text { staining }\end{array}$} \\
\hline & Range $(\mu \mathrm{m})$ & $\operatorname{Mean}(\mu \mathrm{m})$ & $\begin{array}{c}\text { Range } \\
(\mu \mathrm{m})\end{array}$ & $\begin{array}{c}\text { Mean } \\
(\mu \mathrm{m})\end{array}$ & & \\
\hline Xap1 & $1.80-1.94$ & 1.84 & $0.28-0.33$ & 0.30 & + & - \\
\hline Xap2 & $1.73-1.82$ & 1.75 & $0.23-0.26$ & 0.24 & + & - \\
\hline Xap3 & $1.89-1.96$ & 1.91 & $0.30-0.34$ & 0.33 & + & - \\
\hline Xap4 & $1.76-1.85$ & 1.77 & $0.27-0.33$ & 0.32 & + & - \\
\hline
\end{tabular}

Table.7 Pathogenic variability among isolates of Xanthomonas axonopodis pv. Punicae

\begin{tabular}{|c|c|c|l|}
\hline \multirow{2}{*}{ Isolate } & \multicolumn{2}{|c|}{ Lesion size (mm) } & \multicolumn{1}{|c|}{ Symptom appearance } \\
\cline { 2 - 3 } & After 15 days & After 18 days & \multicolumn{1}{|c|}{$\begin{array}{l}\text { Water soaked, circular to irregular, dark brown } \\
\text { spots }\end{array}$} \\
\hline Xap1 & 0.2 & 3.9 & $\begin{array}{l}\text { Water soaked, circular, light brown spots, dark } \\
\text { brown spots }\end{array}$ \\
\hline Xap2 & 0.3 & 3.6 & Water soaked, irregular, light to dark brown spots \\
\hline Xap3 & 1.0 & 4.0 & $\begin{array}{l}\text { Water soaked, circular, dark brown spots, dark } \\
\text { brown spots }\end{array}$ \\
\hline Xap4 & 0.2 & 3.8 & \multicolumn{2}{|l}{} \\
\hline
\end{tabular}


Table.8 Differences in Percent Disease Index (PDI) of Xanthomonas axonopodis pv. Punicae isolates in pomegranate varieties

\begin{tabular}{|c|c|c|c|c|c|c|c|c|c|c|c|c|c|c|c|}
\hline \multirow[b]{2}{*}{$\begin{array}{l}\text { X.axonopodis pv. } \\
\text { Punicae isolates }\end{array}$} & \multicolumn{15}{|c|}{ Pomegranate varieties } \\
\hline & Tobesta & Jyothi & P13 & G-137 & P-26 & $\mathbf{P}-23$ & BT skin & P-16 & Patana-5 & Kalliphathiya & Nana & Ganesh & Bhagawa & Ruby & $\begin{array}{c}\text { Mean } \\
\text { PDI }\end{array}$ \\
\hline Xap 1 & \begin{tabular}{|l|}
41.33 \\
$(39.99)$ \\
\end{tabular} & $\begin{array}{c}34.00 \\
(35.62) \\
\end{array}$ & $\begin{array}{c}63.32 \\
(52.75) \\
\end{array}$ & $\begin{array}{c}52.66 \\
(46.52) \\
\end{array}$ & $\begin{array}{c}55.99 \\
(48.45) \\
\end{array}$ & $\begin{array}{c}33.33 \\
(35.16) \\
\end{array}$ & \begin{tabular}{|c|}
39.33 \\
$(38.76)$
\end{tabular} & $\begin{array}{c}75.99 \\
(60.69) \\
\end{array}$ & $\begin{array}{c}9.34 \\
(17.75) \\
\end{array}$ & $\begin{array}{l}32.00 \\
(34.43)\end{array}$ & $\begin{array}{c}7.34 \\
(15.57)\end{array}$ & $\begin{array}{l}46.66 \\
(43.09)\end{array}$ & $\begin{array}{l}61.32 \\
(51.57)\end{array}$ & $\begin{array}{c}40.66 \\
(39.61) \\
\end{array}$ & $\begin{array}{c}42.38 \\
(40.00)\end{array}$ \\
\hline Хap 2 & $\begin{array}{c}31.33 \\
(33.46) \\
\end{array}$ & \begin{tabular}{c|}
30.66 \\
$(33.62)$ \\
\end{tabular} & $\begin{array}{c}55.32 \\
(48.07) \\
\end{array}$ & $\begin{array}{l}51.33 \\
(45.76) \\
\end{array}$ & $\begin{array}{l}43.33 \\
(41.16) \\
\end{array}$ & $\begin{array}{c}39.33 \\
(38.84) \\
\end{array}$ & \begin{tabular}{|l|}
20.00 \\
$(26.55)$ \\
\end{tabular} & $\begin{array}{l}55.32 \\
(48.09) \\
\end{array}$ & $\begin{array}{l}10.67 \\
(18.92)\end{array}$ & $\begin{array}{l}25.33 \\
(30.19) \\
\end{array}$ & $\begin{array}{c}6.67 \\
(14.89) \\
\end{array}$ & $\begin{array}{l}50.66 \\
(45.38) \\
\end{array}$ & $\begin{array}{l}59.99 \\
(50.80) \\
\end{array}$ & $\begin{array}{l}39.33 \\
(38.82) \\
\end{array}$ & $\begin{array}{c}40.99 \\
(39.38) \\
\end{array}$ \\
\hline Xap3 & $\begin{array}{l}15.33 \\
(23.01) \\
\end{array}$ & \begin{tabular}{|c|}
22.00 \\
$(27.16)$ \\
\end{tabular} & $\begin{array}{l}53.99 \\
(47.29) \\
\end{array}$ & $\begin{array}{l}45.99 \\
(42.70) \\
\end{array}$ & $\begin{array}{l}43.33 \\
(41.16) \\
\end{array}$ & $\begin{array}{l}53.99 \\
(47.29) \\
\end{array}$ & \begin{tabular}{|l|}
41.33 \\
$(40.00)$ \\
\end{tabular} & $\begin{array}{l}37.33 \\
(37.29) \\
\end{array}$ & $\begin{array}{l}13.34 \\
(21.39) \\
\end{array}$ & $\begin{array}{l}26.66 \\
(31.06) \\
\end{array}$ & $\begin{array}{c}6.67 \\
(14.89) \\
\end{array}$ & $\begin{array}{c}41.99 \\
(40.37) \\
\end{array}$ & $\begin{array}{l}43.34 \\
(41.09) \\
\end{array}$ & $\begin{array}{l}38.66 \\
(38.45) \\
\end{array}$ & $\begin{array}{c}34.57 \\
(35.23) \\
\end{array}$ \\
\hline Хар4 & $\begin{array}{l}35.33 \\
(36.46) \\
\end{array}$ & \begin{tabular}{c|}
36.00 \\
$(36.85)$ \\
\end{tabular} & $\begin{array}{l}34.66 \\
(35.83) \\
\end{array}$ & $\begin{array}{l}43.33 \\
(41.12)\end{array}$ & $\begin{array}{l}45.33 \\
(42.30) \\
\end{array}$ & $\begin{array}{l}33.33 \\
(35.16)\end{array}$ & $\begin{array}{l}39.33 \\
(38.76) \\
\end{array}$ & $\begin{array}{l}41.33 \\
(40.01)\end{array}$ & $\begin{array}{l}10.67 \\
(18.92)\end{array}$ & $\begin{array}{l}25.33 \\
(30.19) \\
\end{array}$ & $\begin{array}{l}7.34 \\
(15.3)\end{array}$ & $\begin{array}{l}58.66 \\
(50.08) \\
\end{array}$ & $\begin{array}{l}47.99 \\
(43.85)\end{array}$ & $\begin{array}{l}56.66 \\
(48.87)\end{array}$ & $\begin{array}{c}36.81 \\
(36.70)\end{array}$ \\
\hline Mean & $\begin{array}{c}30.83 \\
(33.23) \\
\end{array}$ & \begin{tabular}{|c|}
30.66 \\
$(33.31)$ \\
\end{tabular} & $\begin{array}{l}51.83 \\
(45.98) \\
\end{array}$ & $\begin{array}{l}48.33 \\
(44.03) \\
\end{array}$ & $\begin{array}{l}46.99 \\
(43.27) \\
\end{array}$ & $\begin{array}{l}39.99 \\
(39.11) \\
\end{array}$ & \begin{tabular}{|l|}
35.00 \\
$(36.02)$ \\
\end{tabular} & $\begin{array}{c}52.49 \\
(46.52)\end{array}$ & $\begin{array}{l}11.00 \\
(19.25)\end{array}$ & $\begin{array}{l}27.33 \\
(31.47)\end{array}$ & $\begin{array}{c}7.00 \\
(15.16)\end{array}$ & \begin{tabular}{|l|}
49.49 \\
$(44.73)$ \\
\end{tabular} & $\begin{array}{c}53.16 \\
(46.83) \\
\end{array}$ & $\begin{array}{l}43.83 \\
(41.44)\end{array}$ & $\begin{array}{c}38.69 \\
(37.82)\end{array}$ \\
\hline \multicolumn{2}{|c|}{ S.Em. \pm isolates } & \multicolumn{2}{|c|}{0.89} & & & & & & & \multicolumn{3}{|c|}{ C.D. $1 \%$ Isolates } & \multicolumn{3}{|c|}{3.37} \\
\hline \multicolumn{2}{|c|}{ S.Em. \pm varieties } & \multicolumn{2}{|c|}{1.67} & & & & & & & \multicolumn{3}{|c|}{ C.D. $1 \%$ Varieties } & \multicolumn{3}{|c|}{6.31} \\
\hline \multicolumn{2}{|c|}{$\begin{array}{c}\text { S.Em. } \pm \\
\text { Isolates } x \text { varieties }\end{array}$} & \multicolumn{2}{|c|}{3.34} & & & & & & & \multicolumn{3}{|c|}{$\begin{array}{c}\text { C.D. } 1 \% \\
\text { Isolates x Varieties }\end{array}$} & \multicolumn{3}{|c|}{12.61} \\
\hline
\end{tabular}

Table.9 Amplicons and their sizes generated in Xap isolates from different sources using BOX, ERIC and REP primers

\begin{tabular}{|c|c|c|c|c|c|c|c|c|c|c|c|c|}
\hline \multirow{2}{*}{ Amplicon size (bp) } & \multicolumn{4}{|c|}{ BOX PCR } & \multicolumn{4}{|c|}{ ERIC PCR } & \multicolumn{4}{|c|}{ REP PCR } \\
\hline & Xap1 & Xap2 & Xap3 & Xap4 & Xap1 & Xap2 & Xap3 & Xap4 & Xap1 & Xap2 & Xap3 & Xap4 \\
\hline 2000 & + & + & + & + & + & + & + & + & - & - & - & - \\
\hline 1500 & + & + & + & + & & & & & + & + & + & + \\
\hline 1300 & + & + & + & + & + & + & + & + & - & - & - & - \\
\hline 1000 & + & + & + & + & & & & & + & + & + & + \\
\hline 850 & - & - & - & - & + & + & + & + & + & + & + & + \\
\hline 750 & + & + & + & + & & & & & - & - & - & - \\
\hline 680 & + & + & + & + & & & & & - & - & - & - \\
\hline 600 & + & + & + & + & + & + & + & + & - & - & - & - \\
\hline 500 & + & + & + & + & & & & & + & + & + & + \\
\hline 450 & + & + & + & + & & & & & + & + & + & + \\
\hline 400 & + & + & + & + & & & & & - & - & - & - \\
\hline 300 & + & + & + & + & & & & & - & - & - & - \\
\hline 200 & - & - & - & - & + & + & + & + & + & + & + & + \\
\hline No. of amplicons & 7 & 7 & 7 & 7 & 5 & 5 & 5 & 5 & 6 & 6 & 6 & 6 \\
\hline
\end{tabular}


Table.10 Reaction of pomegranate genotypes against bacterial blight disease under in vivo condition

\begin{tabular}{|c|c|c|l|l|}
\hline Rating & $\begin{array}{c}\text { Percentage } \\
\text { blighted area on } \\
\text { leaf (\%) }\end{array}$ & $\begin{array}{c}\text { Number of } \\
\text { genotypes }\end{array}$ & \multicolumn{1}{|c|}{ Reaction } & \multicolumn{1}{|c|}{ Genotypes } \\
\hline 0 & Disease free & 01 & Resistant & Nana \\
\hline 1 & $1-10$ & 02 & Tolerant & Patna-5, PK20-70 \\
\hline 2 & $11-25$ & 12 & $\begin{array}{l}\text { Moderately } \\
\text { susceptible }\end{array}$ & $\begin{array}{l}\text { PK10-10, PK10-63, } \\
\text { PK10-131,PK10-134, } \\
\text { PK20-62, PK20-157, } \\
\text { PK20-228,PG25-46, } \\
\text { PG25-82, G-137, Co- } \\
\text { white }\end{array}$ \\
\hline 3 & $26-50$ & 272 & Highly susceptible & \\
\hline 4 & $51-75$ & 188 & Highly susceptible & \\
\hline 5 & $76-100$ & 01 & Highly susceptible & \\
\hline
\end{tabular}

Table.11 Reaction of pomegranate genotypes against bacterial blight disease under in vitro condition

\begin{tabular}{|c|c|c|c|c|}
\hline Rating & $\begin{array}{c}\text { Percentage } \\
\text { blighted area on } \\
\text { leaf }(\%)\end{array}$ & $\begin{array}{l}\text { Number of } \\
\text { genotypes }\end{array}$ & Reaction & Genotypes \\
\hline 0 & Disease free & 01 & Resistant & Nana \\
\hline 1 & $1-10$ & 01 & Tolerant & \begin{tabular}{|l|} 
PG20-80 \\
\end{tabular} \\
\hline 2 & $11-25$ & 17 & $\begin{array}{l}\text { Moderately } \\
\text { susceptible }\end{array}$ & $\begin{array}{lr}\text { PK10-134, } & \text { PK20-92, } \\
\text { PK20-228, } & \text { PG15-9, } \\
\text { PG20151, } & \text { PG25-4, } \\
\text { PG25-46, } & \text { PG25- } \\
\text { 82,Early } & \text { Bhagwa, } \\
\text { Yarcaud, } & \text { Tobesta, } \\
\text { Kabuli yellow,P-13, } & \text { yellana } \\
\text { Bedandess, G- } \\
\text { 137, Jallore } & \text { seedless, } \\
\text { Patna5, } & \end{array}$ \\
\hline 3 & $26-50$ & 276 & Highly susceptible & \\
\hline 4 & $51-75$ & 179 & Highly susceptible & \\
\hline 5 & $76-100$ & 01 & Highly susceptible & \\
\hline
\end{tabular}




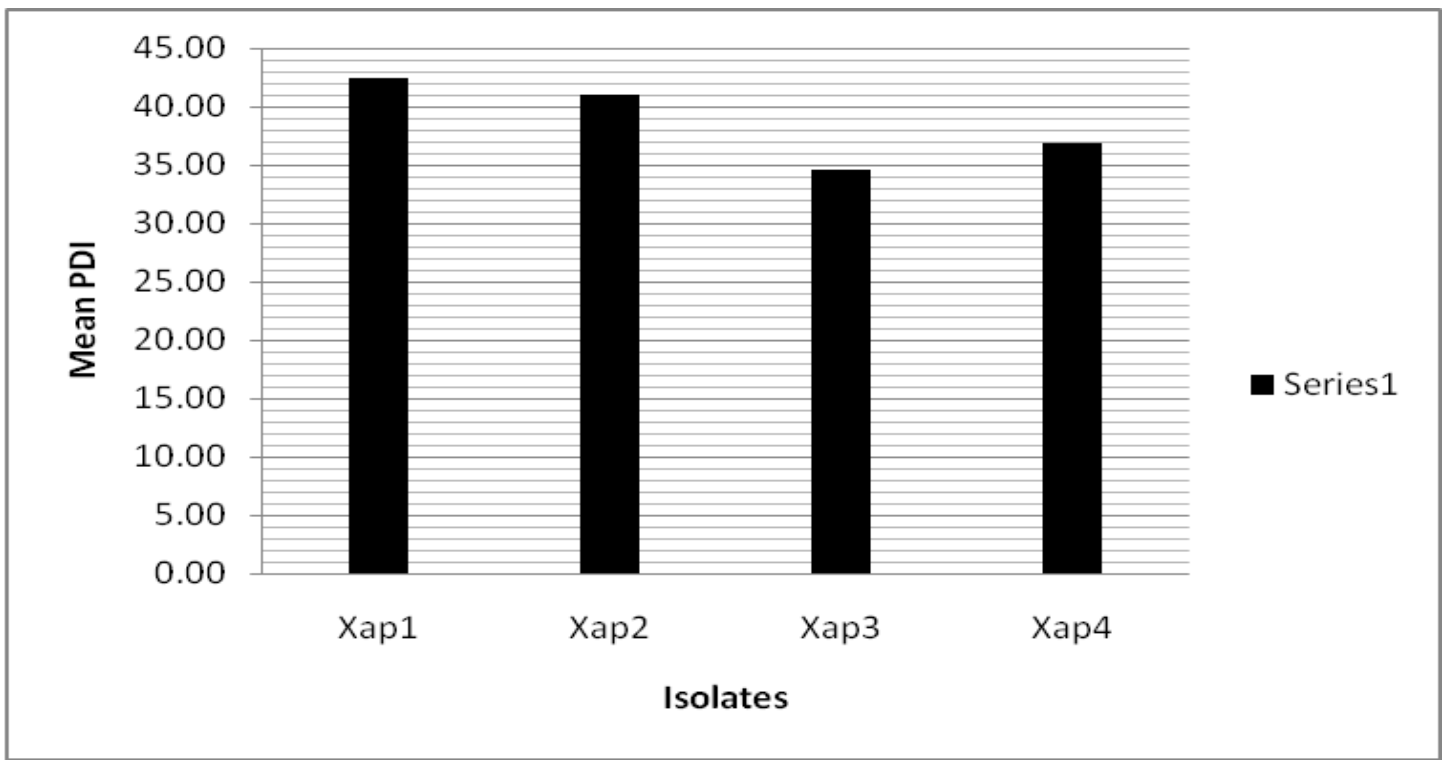

Fig.1 Variation in virulence of Xanthomonas axonopodis pv. Punicae isolates infecting pomegranate

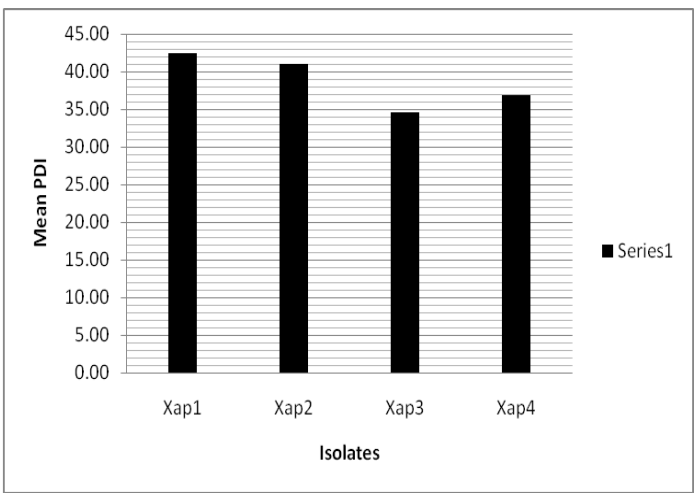

Plate.1 Pure culture of $X$. axonopodis pv. punicae

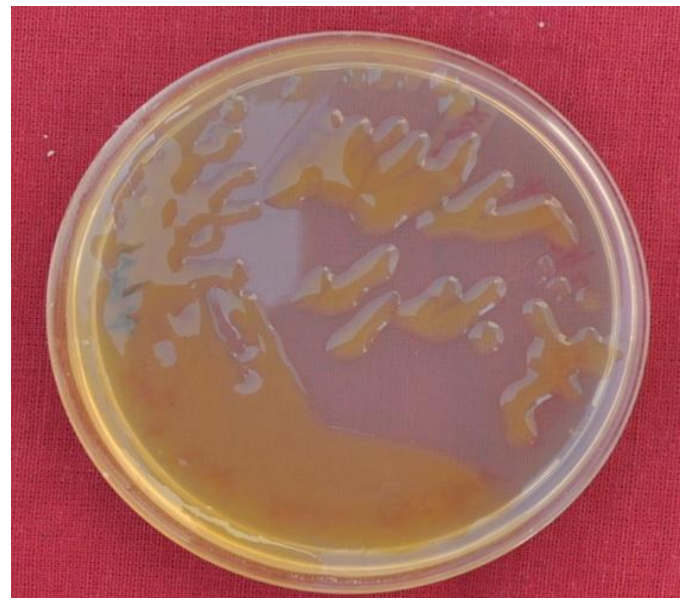

Fig.2 Variation in varietal susceptibility of pomegranate to Xanthomonas axonopodis pv. Punicae isolates

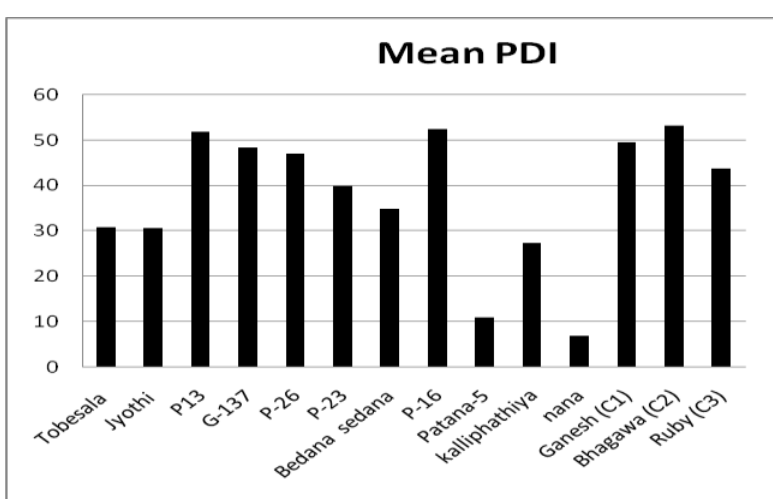

Plate.2 Initial water soaked symptoms on lower leaf surface

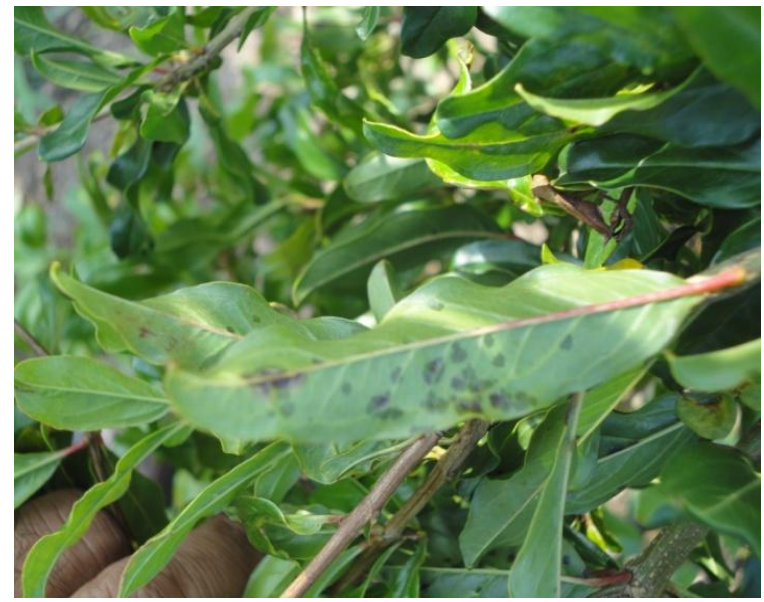


Plate.3 Pathogenicl variability of X.axonopodis $p v$. Punicae on suceptible pomegranate cv.Bhagawa

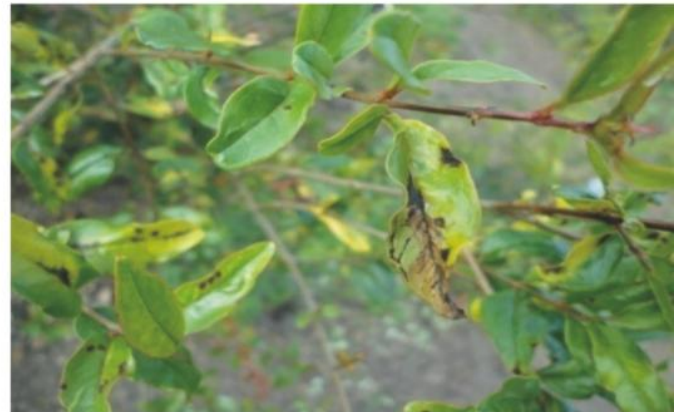

Xap1

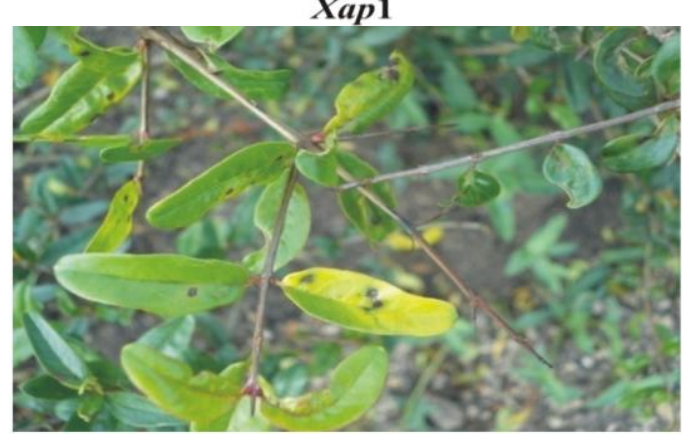

Xap3

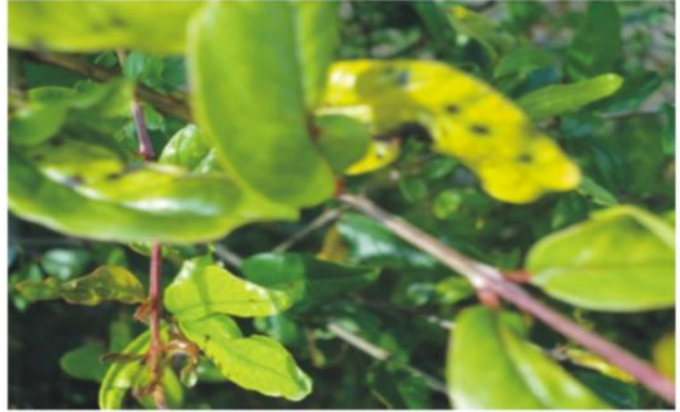

Xap2

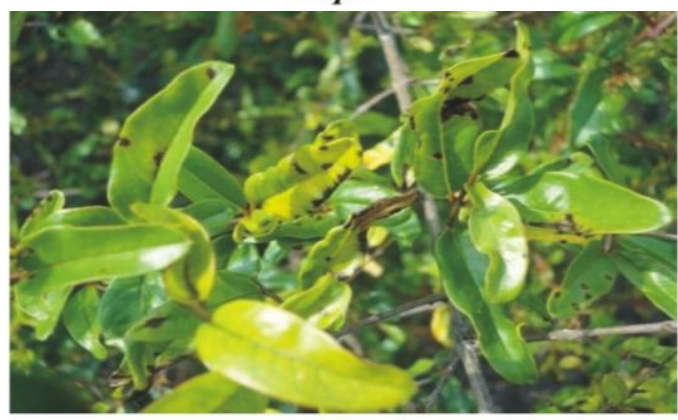

Xap4

Plate.4 PCR ampllification with 16srRNA primer and PCR ampllification with gyrB primer
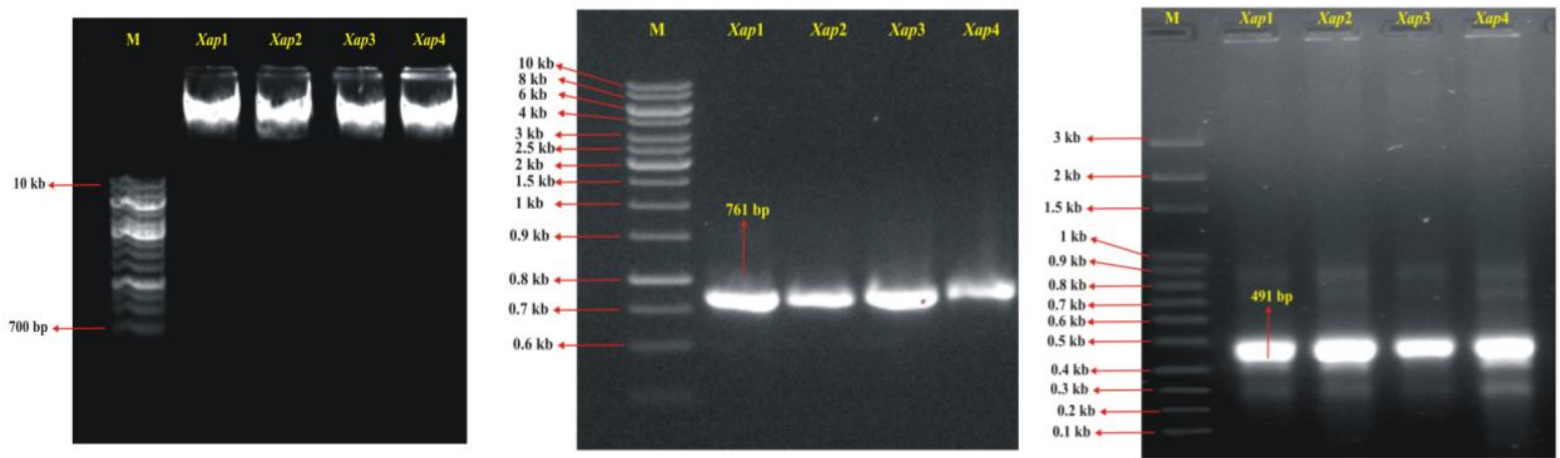

Plate.5 BOX, ERIC and Rep PCR generated genomic finger prints

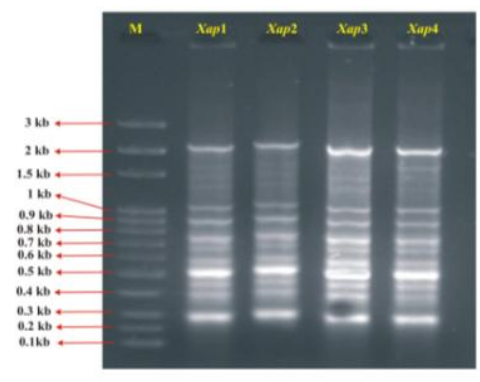

BOX PCR

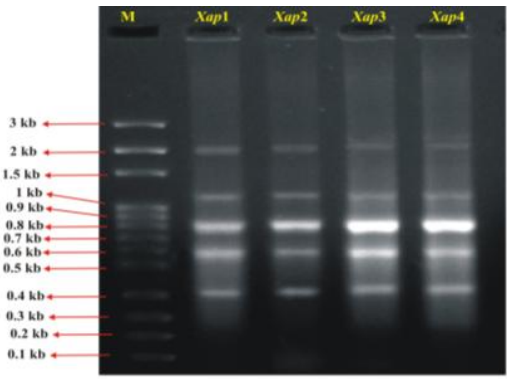

ERIC PCR

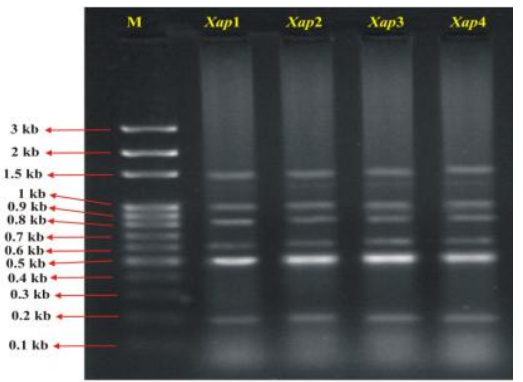

Rep PCR 
It was observed that the interaction between varieties and isolates was statistically significant. Highest PDI (75.99) was recorded in interaction between P-16 x Xap 1 followed by P-13 X Xap 1 (63.32) and it was least with Nana x Xap2 (6.67), Nana x Xap3 (6.67) followed by Nana $x$ Xap 1 (7.34) and Nana $x$ Xap4 (7.34).

There was considerable variation in virulence of isolates and susceptibility of varieties. Isolates Xap1 (PDI 42.38) and Xap2 (PDI 40.99) were found more virulent irrespective of varieties compared to other isolates. Varieties Bhagawa, P-13 and Ganesh were found to be highly susceptible irrespective of isolates and recorded maximum mean PDI of 53.16, 51.83 and 49.49 respectively. Patna-5 and Nana showed uniform resistant reaction against four isolates.

The four isolates were characterized based on the 16S rRNA and gyrB gene analysis. Four isolates were used for the amplification of 761 bp of the 16s rDNA coding region and $491 \mathrm{bp}$ of $g y r B$ gene The amplicon size of around $761 \mathrm{bp}$ and $491 \mathrm{bp}$ were noticed in all the four isolates using $16 \mathrm{~S}$ rRNA and $g y r B$ gene primer and conforms that, all these isolates belong to Xap (Plate 5). A more conserved genetic characteristics, the 16S-23S intergenic spacer (IGS) of rDNA operon, has also been used to infer the phylogenetic relationship and identification of bacteria at different taxonomic levels (Gurtler and Stanisich, 1996). The 49 strains tested were amplified and produced a single band with each primer set and these sizes corresponded to the expected sizes of the targeted 16S rRNA and 23S rRNA genes respectively. For the ITS region, they produced a band of approximately $1600 \mathrm{bp}$ and the resulting size of the ITS region ranged from 500 to $550 \mathrm{bp}$ (Hirokaku Ochial and Hisatoshi Kaku, 1999). It was the expected size, since they have recently determined the sequence of this region among Xanthomonas strains.
Amplification of ERIC, BOX and Rep region of DNA from four isolates of pomegranate bacterial blight disease from four locations with three different primers yielded a total 28 , 20 and 24 bands respectively (Table 9 and Plate 6) with monomorphic banding pattern in all four isolates and amplicon size ranging from 300 to $2000 \mathrm{bp}$ with BOX and ERIC primers whereas in case of Rep primers the range is 200 to 1000 bp only. From this it is confirmed that not much variation is existing in the collected isolates. Hence, isolate from Vijayapur was used for the further screening of the pomegranate genotypes against bacterial blight disease both in vivo and in vitro. The ERIC-PCR has been demonstrated to be an effective method in determining the genetic diversity among the population of many bacterial plant pathogenic genera, including Xanthomonas and Pseudomonas (Louws et al., 1994; Louws et al., 1998). Minhaj Arshiya et al., (2014) isolated 56 strains of Xanthomonas axonopodis pv citri (Xac) from different citrus growing areas of Marathwada region of Maharashtra state and 20 representative strains of $X a c$ were selected for genetic diversity. Repetitive DNA polymerase chain reaction-based fingerprinting (rep-PCR) using repetitive extragenic palindromic (rep) and enterobacterial repetitive intergenic consensus (ERIC) and BOX primers were used to assess the genetic diversity.

The Bacterial blight incidence (in vivo) was recorded during Mrigh bahar 2014-15 and 2015-16 using 0-5 scale. The results are presented in table 10 . The mean value among all genotypes was 43.39 (PDI) with a range of 9.52 (Nana) to 56.11 (PG25-82). Further, these 475 genotypes were grouped in to five categories. Out of 475 genotypes only one (nana) was found to be tolerant, only two genotypes Patna-5 and PK20-70 were found to be tolerant with a rating of $1 ; 12$ genotypes were found moderately susceptible, while, 272 genotypes were found highly susceptible 
with rating of 3 . Only one genotype was found highly susceptible. The remaining 188 recorded a rating of 4, with highly susceptibility. The check varieties Bhagawa, Ganesh and Ruby found to be highly susceptible to Bacterial blight in both the seasons.

The grouping of all the genotypes for bacterial blight disease (in vitro) is presented in table 11 . The results indicates that the mean value among all the genotypes was 45.93 PDI with a range of 0 (Nana) to 82.65 PDI (PK20160). Further, these 475 genotypes were grouped in to 5 categories. Out of 475 genotypes, nana and PG20-80 was found to be resistant and tolerant respectively. Only 17 genotypes were found to be moderately susceptible with a rating of 2 .

Majority of genotypes were found to be highly susceptible, with 276 in rating 3 and 179 genotypes in a rating of 4 . Only one genotype was found highly susceptible. The check varieties Bhagawa, Ganesh and Ruby showed highly susceptible to Bacterial blight in both the seasons and results are in accordance with Ashish and arora, 2014; Katwal 2015 and Priya et al., 2016

On the basis of the present study, it could be concluded that the population of bacterial blight pathogen $X$. axonopodis pv. punicae in Karnataka are genetically homogenious and showed similar banding pattern from ERIC, BOX and Rep profiles, and isolate from vijayapur region(Xap1) was used for the further screening of $\gamma$ irradiated seed derived progenies and germplasms of pomegranate.

\section{Acknowledgment}

The authors are thankful to Department of Biotechnology and Crop Improvement, Horticulture Research and Extension Station, Vijayapur (Tidagundi), University of
Horticultural Sciences, Bagalkot, Karnataka, India for providing necessary facilities to complete the research work.

\section{References}

Anonymous, 2015, Area and Production. http://www. NHBdatabase.com.

Ashish and Arora, A., 2014, Screening of pomegranate germplasm against bacterial blight. HortFlora Res. Spectrum, 3 (2): 169-171

Benagi, V. I. and Kumar, R. M. R., 2009, Present status of pomegranate bacterial blight and its management. In: $2^{\text {nd }}$ International Symposium on Pomegranate and Minor including Mediterranean Fruits, UAS, Dharwad (pp 53-58) from 23/6/09 to 27/6/09.

Chand, R. and Kishun, R., 1991, Studies on bacterial blight (Xanthomonas campestris pv. punicae) of pomegranate. Indian Phytopathology, 44: 370-371.

Chand, R. and Kishun, R., 1993, Systemic movement of Xanthomonas campestris pv. punicae (Hingorani and Singh) dye from leaf to node in pomegranate. Int. J. Trop. Dis., 11(1), 85-90.

Gurtler, V. and Stanisich, V. A., 1996, New approaches to typing and identification of bacteria using $16 \mathrm{~S}-23 \mathrm{~S}$ rDNA spacer region. Microbiology, 142:3-16

Hingorani, M. K. and Mehta, P. P., 1952, Bacterial leaf spot of pomegranate. Indian Phytopathol, 5: 55-56.

Hingorani, M. K. and Singh, N. J., 1959, Xanthomonas sp. nov. On Punica granatum L. Indian J. Agril. Sci., 29: 4548.

Hirokaku Ochiai and Hisatoshi Kaku, 1999, Genetic relationships among Xanthomonas species and pathovars based on RFLP analysis of PCR amplified 16S, 23S rDNA and rDNA internal transcribed spacer. Ann. Phytopathol. Soc. Japan, 65:437-446

Jain, S. M., 2010, Mutagenesis in crop improvement under the climate change. 
Romanian Biotechnol. Letters, 15: 88106.

Jalikop, S. H. and Kumar, P. S., 1990, Use of gene marker to study the mode of pollination in pomegranate (Punica granatum L). J. Hort. Sci., 65 (2): 221223.

Jyoti Gildiyal, 2017, Studiies on variability and management of Bacterial blight $(X$. axonopodis pv.punicae (Hingorani and Singh) Vateriun et al., M. Sc. Thesis, Dr. Y. S. Parmar University of Horticulture and forestry, Solan.

Kanwar, Z. S., 1976, a note on bacterial disease of pomegranate (Punica granatum L.) in Haryana. Haryana J. Hort. Sci., 5: 177180.

Katwal, V. S., 2015, Studies on bacterial blight of pomegranate caused by Xanthomonas axonopodis pv. punicae (Hingorani and Singh) Vauterin et al., Ph. D. Thesis, Dr Yashwant Singh Parmar University of Horticulture and Forestry, Nauni Solan (HP), INDIA

Kirankumar, K. C., 2007, Molecular characterization of X.auxonopodis pv.punicae, causing bacterial blight of pomegranate, its epidiomology and integrated management. Ph. D. Thesis, Univ. Agric. Sci., Bangalore

Kumar, R., Shamarao, J. M. R., Yenjerappa, S. T., Patil, H. B., 2009, Epidemiology and management of bacterial blight of pomegranate caused by Xanthomonas axono-podis pv. Punicae. Acta Horticul. 818:291-296.

Larik, A. S., Memon, S. and Soomro, Z. A., 2009, Radiation induced polygenic mutations in Sorghum bicolor. J. Agric. Res., 47: 11-19.

Louws, F. J., Bell, J., Medina Mora, C. M., Smart, C. D., Opgenorth, D., Ishimaru, C. A., Housebeck, M. K., de Bruijn, F. J. and Fulbright, D. W., 1998, Rep- PCR mediated genomic fingerprinting: a rapid and effective method to identify clavibacter michiganensis. Phytopathology, pp. 862-868

Louws, F. J., Fulbright, D. W., Stephens, C. T., de Bruijn, F. J., 1994, Specific genomic fingerprints of phytopathogenic Xanthomonas and Pseudomonas pathovars and strains generated with repetitive sequences and PCR. Appl. Environ. Microbiol, 60:2286-2295

Malhotra, V. K., Khajuria, H. N. and Jawanda, J. S., 1983, Studies on physico-chemical characters of pomegranate cultivars II. Chemical characters. Punjab Hort. J., 23: 158-161.

Manjula, C. P. and Khan, A. N. A., 2002, Incidence of bacterial blight of pomegranate (Punica granatum L.) in Karnataka. In: Annual Meeting and Symposium on Plant Disease Scenario in Southern India, held at Bangalore (India), December 19-21. pp. 51-52.

Manjula, C. P. and Khan, A. N. A., 2003, Incidence of bacterial blight of pomegranate (Punica granatum L.) in Karnataka. Indian Phytopathol, 56(3): 341

Manjula, C. P., 2002, Studies on bacterial blight of pomegranate (Punica granatum L.) caused by X.axonopodis pv. punicae. $M$. Sc. (Agri.) Thesis, Univ. Agric. Sci., Bangalore.

Minhaj Arshiya, Alka Suryawanshi, Digamber More and Mirza Mushtaq Vaseem Baig. Repetitive PCR based detection of Genetic Diversity in Xanthomonas axonopodis pv citri Strains. J. App. Biol. Biotech., 2014; 2 (01): 017-022.

Mondal, K. K. and Mani, C., 2009, ERIC-PCR generated genomic fingerprints and their correlation with patho-genic variability of Xanthomonas campestris pv. punicae, the incitant of bacterial blight of pomegranate. Curr. Microbiol. 59: 616620.

Mondal, K. K. and Sharma, J., 2009, Bacterial blight: An emerging threat to pomegranate export. Indian Farming, 59: 22-23.

Mondal, K. K. and Singh, D., 2009, Bacterial blight of pomegranate-A technical bulletin. Division of Plant Pathology. Indian Agric. Res. Inst. New Delhi. : 8. 
Mondal, K. K., Rajendran, T. P., Phaneendra, C., Mani, C., Sharma, J., Shukla, R., Pooja, Verma G., Kumar R., Singh D., Kumar A., Saxena, A. K. and Jain, R. K.,2012, The reliable and rapid polymerase chain reaction (PCR) diagnosis for Xanthomonas axonopodis pv. punicae in pomegranate. Afr. J. Microbiol. 6 (30), pp. 5950-5956,

Parkinson, N., Cowie, C., Heeney. J. and Stead, D., 2009, Phylogenetic structure of Xanthomonas determined by comparison of gyrB sequences. Int. J. Syst. Evol. Microbiol, 59: 264-274.

Parry, M. A., Madgwick, P. J., Bayon, C., Tearall, K., Hernandez-Lopez, A., Baudo, M., Rakszegi, M., Hamada, W., AYassin, A., Ouabbou, H., Labhilili, M. and Phillips, A. L., 2009, Mutation discovery for crop improvement. J. Exptl. Botany., 60: 2817-2825.

Petersen, Y., Mansvelt, E.L., Venter, E. and Langenhoven, W. E., 2010, Detection of Xanthomonas axonopodis pv. Punicae causing bacterial blight on pomegranate in South Africa. J. Austrian Pl. Pathol. 39:544-546

Priya, T. B., Murthy, B. N. S., Gopalakrishnan, C., Rashmi, B., Artal, S. Jagannath, S., 2016, Identification of new resistant sources for bacterial blight in pomegranate. Eur J Plant Pathol DOI 10.1007/s10658-016-0947-1

Raghavan, R., 2007, Oily spot of pomegranate in India (Maharashtra), Express India Sharma, K.K. (2006). Important diseases, disorders and insect pests of Pomegranate and their management. Tech. Bull. NRCP, Solapur. : 2-3.
Sharma, K. K., Sharma, J. and Jadhav, V. T., 2010, Status of bacterial blight of pomegranate in India. In: Fruit, vegetable, cereal science and biotechnology (special issue 2) (pp. 102-105). Japan: Global Science Books (pub.).

Sharma, K. K., Sharma. J., Jadhav, V. T. and Chandra, R., 2008, Bacterial blight of pomegranate and its manage-ment. Indian Pytopathol. 61 (3): 380-381.

Sharma, K.K. (2006). Important diseases, disorders and insect pests of Pomegranate and their management. Tech. Bull. NRCP, Solapur. : 2-3.

Singh, N. V. Abburi, V. L., Ramajayam, D., Kumar, R., Chandra, R., Sharma, K. K., Sharma, J. K., Babu, K., 2015, Genetic diversity and association mapping of bacterial blight and other horticulturally important traits with microsatellite markers in pomegranate from India. $\mathrm{Mol}$ Genet Genomics, pp. 51-83.

Vauterin, L., Hoste, B., Kersters, K. and Swings, J., 1995, Reclassification of Xanthomonas. Int. J. Systematic Bacteriol, 45: 475-489.

Wayde, J. E., Akshay, S. D., Trishala, A. P.., Deepak, R. S. and Monika, B., 2015, Assessment of the genetic diversity among oily spot (Xanthomonas axonopodis pv. punicae).

Yenjerappa, S. T., 2009, Epidemiology and management of bacterial blight of pomegranate caused by xanthomonas axonopodis pv. punicae (hingorani and singh) vauterin Ph. D. (Agri.) Thesis, Univ, Agric. Sci., Daharwad, Karnataka (India).

\section{How to cite this article:}

Dadepeer A. Peerajade, Narayan Moger and Patil, H.B. 2017. Studies on Variability, Identification of Xanthomonas axonopodis pv. punicae Isolates and Screening of Gamma ( $\square$ ) Irradiated Seed Derived Progenies and Germplasms of Pomegranate. Int.J.Curr.Microbiol.App.Sci. 6(8): 2987-3002. doi: https://doi.org/10.20546/ijcmas.2017.608.358 